\title{
PERBANDINGAN EFEKTIVITAS AROMATERAPI PEPPERMINT DAN LAVENDER TERHADAP PENURUNAN EFEK MUAL MUNTAH POST KEMOTERAPI
}

\author{
Lailatus Siyamu Nurrohmi, Sih Ageng Lumadi, Risna Yekti Mumpuni \\ STIKes Maharani Malang Jawa Timur, Indonesia \\ Email: lailatussiyamu@gmail.com, lumadi@ymail.com, \\ mumpunirisnayekti@gmail.com
}

\begin{abstract}
Abstrak
Mual Muntah adalah efek samping paling umum terjadi pada kemoterapi. Meskipun dengan berkembangnya terapi farmakologis mual muntah tetaplah menjadi masalah utama kemoterapi. Dengan bertambahanya terapi non farmakologi untuk antimual salah satunya aromaterapi diharapkan mampu membantu mengurangi efek mual muntah akibat kemoterapi. Penelitian ini bertujuan untuk membandingkan efektifitas aromaterapi peppermint dan lavender dalam menurunkan mual muntah post kemoterapi. Penelitian kuantitatif ini menggunakan pendekatan cross sectional dengan metode penelitian PraEksperimental Design, untuk desain penelitian menggunakan One group pretestposttest design. Sampel berjumlah 38 responden yang dibagi 2 kelompok berdasarkan dengan jenis kanker, regimen dan siklus kemoterapi yang sama kemudian diberikan aromaterapi berbeda. Penelitian ini menguji pengaruh setiap aromaterapi dengan uji Wilcoxon kemudian membandingkan efektivitasnya menggunakan uji statistik SPSS for Windows Mann-Whitney dikarenakan distribusi data tidak normal setelah diuji dengan shapiro wilk dari uji pengaruh ditemukan hasil p-Value <,001 artinya baik aromaterapi Peppermint dan lavender memiliki pengaruh terhadap penurunan mual muntah post kemoterapi. Berdasarkan hasil rank statistic didapatkan aromaterapi Lavender mendapatkan Rank tertinggi dalam menurunkan mual muntah. Namun, uji beda Mann-Whitney menunjukkan nilai Signifikansi sebesar 0,546 lebih besar dari 0,05 sehingga diartikan tidak terdapat perbedaan yang signifikan dari kedua kategori aromaterapi peppermint dan lavender terhadap penurunan mual muntah post kemoterapi. Aromaterapi peppermint dan lavender dapat digunakan sebagai antimual dalam penatalaksananaan mual muntah post kemoterapi karena Kandungan menthol didalam aromaterapi peppermint sebagai antimual dan linalool pada lavender yang bersifat anticemas mampu menurunkan mual muntah 1-2 skala mual mulai dari mual-muntah berat ke ringan.
\end{abstract}

Kata Kunci: aromaterapi; peppermint; lavender; mual muntah; kemoterapi

\begin{tabular}{ll} 
Abstract & \\
& \\
\hline How to cite: & $\begin{array}{l}\text { Nurrohmi. L.S., Sih Ageng Lumadi \& Risna Yekti Mumpuni (2021). Perbandingan Efektifitas Aroma Terapi } \\
\text { Peppermint Dan Lavender Dalam Mengurangi Mual Dan Muntah Post Kemoterapi. Syntax Literate: Jurnal } \\
\end{array}$ \\
Ilmiah Indonesia, 6(12). http://dx.doi.org/10.36418/ Syntax-Literate.v6i12.5048
\end{tabular}


The side effect of chemotherapy that is difficult to manage until now is nausea and vomiting. So far, the treatment of nausea and vomiting due to chemotherapy in the hospital has only provided pharmacological therapy and there has been no additional nonpharmacologic therapy. This research aims to compare the effectiveness of aromatherapy Peppermint and Lavender in reducing post chemotherapy nausea and vomiting. This quantitative research uses a cross sectional approach with the method of Pre-Experimental Design, for the research design using the One group pretest-posttest design. The sample amounted to 38 respondents who were divided into 2 groups based on the type of cancer, regimen and cycle of the same chemotherapy and then given different aromatherapy. Researchers tested the effect of each aromatherapy with the Wilcoxon test and then compared its effectiveness using the SPSS for Windows Mann-Whitney statistical test because the data distribution was not normal after being tested with Shapiro Wilk. From the effect test, it was found that the p-Value <.001 means that both Peppermint and lavender aromatherapy have an effect on reducing post-chemo nausea and vomiting. And based on the statistical rank results, Lavender aromatherapy got the highest rank in reducing nausea and vomiting. However, the Mann-Whitney showed different result, Asymp. Sig. (2-tailed) result is 0.546 greater than 0.05, its means that there was no significant difference between the two categories of peppermint and lavender aromatherapy on reducing postchemotherapy nausea and vomiting. Peppermint and Lavender aromatherapy can be used as antiemetic in the management of post-chemotherapy nausea and vomiting because of menthol substance in peppermint aromatherapy as an antinausea and linalool in lavender which is anti-anxiety effectively lowers nausea vomiting 1-2 nausea scale from severe to light.

Keywords: aromatherapy; peppermint; lavender; nausea vomiting; chemotherapy

Received: 2021-11-20; Accepted: 2021-12-05; Published: 2021-12-20

\section{Pendahuluan}

Penyakit kanker adalah suatu proses penyakit yang bermula ketika sel abnormal diubah oleh mutasi genetik dari Deoxyribo Nucleic Acid (DNA) selular. Sel abnormal ini selanjutnya akan membentuk klon dan mulai berproliferasi secara abnormal. Kemudian mencapai tahap di mana sel menjadi invasif, dan membuat perubahan pada jaringan sekitarnya. Sel-sel yang invasive akan menginfiltrasi jaringan sekitar serta limfe dan pembuluh-pembuluh darah. Ketika mencapai pembuluh darah tersebut sel-sel dapat menyebar keseluruh area lain dalam tubuh untuk membentuk metastase (penyebaran kanker) pada bagian tubuh yang normal (Rukayah, 2015). Kematian akibat kanker tertinggi di dunia adalah kanker paru sebesar 1,8 kematian yang diikuti oleh kematian akibat kanker kolorektal, kanker lambung, kanker hati, dan kanker payudara. Kematian akibat kanker di antaranya ditentukan oleh prognosis jenis kanker yang diidap oleh pasien. Kualitas pelayanan kesehatan yang diberikan pada proses pengobatan juga mempengaruhi prognosis pasien (Ministry of Health RI., 2019).

Beberapa modalitas pengobatan kanker yang saat ini tersedia di RS rujukan Kanker yaitu: operatif, radioterapi, kemoterapi dan terapi target. Sampai sekarang 
kemoterapi tetap menjadi pilihan utama bagi perawatan bagi penderita kanker. Baik sebagai terapi sendiri maupun digabung dengan terapi lainnya (Nindya and Surarso, 2016). Di Indonesia sendiri memiliki RS rujukan Kanker tersebar di berbagai provinsi. Provinsi Jawa Timur sendiri yang memiliki jumlah penduduk terbanyak memiliki layanan kemoterapi yang terpusat di kota Surabaya dan Malang (Petrarizky \& Nugroho, 2020).

Meskipun kemoterapi kebanyakan sebagai pilihan utama dalam pengobatan kanker, kemoterapi juga memiliki efek samping yang cukup banyak. Selain dapat membunuh sel yang bermutasi, obat kemoterapi juga berefek pada sel-sel sehat dan normal. Efek samping kemoterapi yang paling umum dan sulit untuk dikelola menurut penelitian terbanyak adalah mual muntah. Sebanyak 75 pasien $(83,3 \%)$ mengalami mual dan 71 pasien $(78,9 \%)$ mengalami muntah dari total 90 pasien yang menjalani (Hamdani \& Anggorowati, 2019). Hal ini disebabkan adanya stimulus dari zat sitotastika dalam kemoterapi yang dapat mengaktifkan chemoreseptor trigger zone (CTZ) di medulla dimana CTZ berperan sebagai reseptor yang menimbulkan mual muntah. Penanganan mual muntah yang tidak tepat dapat menurunkan tingkat kepatuhan pasien dan menimbulkan gangguan aktifitas fungsional pasien. Kemoterapi adalah terapi yang berkelanjutan, mual muntah yang berkepanjangan membuat pasien mengalami kekurangan cairan dan nutrisi. Dengan kondisi tubuh seperti itu dikhawatirkan tubuh tidak akan siap saat menerima kemoterapi selanjutnya (Gupta et al., 2021).

Selama ini pasien yang mengalami mual dan muntah akibat kemoterapi dirumah sakit hanya diberi penanganan dengan terapi farmakologis berupa pemberian antiemetik. Antiemetik adalah zat-zat yang dapat mengatasi rasa mual dan muntah. Meskipun dapat mengatasi mual dan muntah, antiemetik sama seperti obat-obatan lain yang berpotensi menimbulkan efek samping. Efek samping umum yang biasa ditimbulkan adalah mengantuk, mulut kering, gangguan pencernaan, konstipasi dll (lihara et al., 2016). Untuk itu perlu adanya terapi tambahan yang efektif dalam membantu menurunkan gejala mual dan muntah akibat kemoterapi dan tentunya yang tidak menimbulkan efek samping. Terapi ini merupakan intervensi mandiri perawat dalam mengatasi keluhan pasien yang dilakukan untuk mendukung pengobatan medis. Terapi yang sering digunakan secara umum mengurangi efek mual muntah selama kemoterapi adalah aromaterapi. Aroma terapi banyak dipilih karena mudah dan terjangkau. Sehingga di negara-negara maju aromaterapi telah dipilih sebagai terapi koplementer bagi pelayanan keperawatan. Sebagian negara yang menggunakan aromaterapi sebagai tambahan praktek keperawatan mereka antara lain Swiss, Jerman, Inggris, Kanada dan Amerika Serikat (Hamdani \& Anggorowati, 2019).

Di Indonesia sudah memiliki beberapa penelitian tentang efektifitas aromaterapi sebagai terapi komplementer. Salah satu penelitian yang peneliti temukan pada pasien kemoterapi yang mual muntah di RS SMC Telogorejo sesudah diberikan perlakuan aromaterapi peppermint untuk efek mual muntah kemo skala mual ringan mengalami peningkatan yaitu dari 8 pasien $(53,3 \%)$ menjadi 13 pasien $(86,7 \%)$ dan pada skala mual 
sedang mengalami penurunan yaitu dari 7 pasien (46,7\%) menjadi 2 pasien $(13,3 \%)$ (Sari et al., 2015). Aromaterapi peppermint mengandung menthol (35-45\%) dan menthone (10\%-30\%) sehingga dapat bermanfaat sebagai antimual dan antikejang pada lapisan lambung dan usus dengan menghambat kontraksi otot yang disebabkan oleh serotonin dan substansi lainnya (Rapoport, 2017). Efek antimual dari peppermint ini berguna untuk menurunkan mual muntah pada pasien kemoterapi. Selain aroma terapi peppermint, penggunaan aromaterapi lavender juga sering dipergunakan untuk mengurangi mual dan muntah pada pasien kemoterapi. Sebuah studi tentang perlakuan aromaterapi lavender pada mual muntah peneliti temukan pada pasien kanker payudara yang menjalani kemoterapi di RSUD dr. Soetomo surabaya menunjukkan aromaterapi lavender yang dilakukan rutin selama tiga minggu berturut-turut mampu menurunkan nausea dan vomiting pasien kanker payudara yang menjalani kemoterapi (Anisa et al., 2019).

Aroma terapi lavender sendiri adalah esensial lavender (Lavandula Angustifolia) mengandung linalool, linalyl acetate, cineol, lavender, geraniol tannin, flavonoids yang dapat menimbulkan efek antibacterial, antispasmodic, antidepresant dan analgesik. Kandungan linalool yang bersifat sedative dan linalyl acetate yang memberikan efek narkotik dapat menekan aktivitas sistem saraf simpatis, mengurangi hormon stres dan meningkatkan sekresi beta-endorphins. Dengan efek sedasinya dapat menstimulasi reseptor mual muntah di otak sehingga menurunkan efek samping mual muntah kemoterapi (Arifah, 2018).

Dari fenomena diatas maka peneliti memiliki ketertarikan sendiri untuk melakukan penelitian tentang perbandingan efektifitas aroma terapi peppermint dan lavender dalam mengurangi mual dan muntah post kemoterapi. Mual muntah yang berkelanjutan dan tidak diatasi dengan segera dapat menimbulkan beberapa akibat yang tidak baik bagi tubuh antara lain menganggu asupan gizi bagi pasien kemoterapi. Dimana mereka seharusnya membutuhkan energi yang mencukupi setelah dimasukkan obat kemoterapi yang berefek kuat.

Tujuan dari penelitian ini adalah mengetahui perbandingan efektivitas pengaruh aromaterapi peppermint dan lavender terhadap penurunan mual dan muntah setelah menjalani kemoterapi. Hasil penelitian dapat menjadi acuan dan perbandingan untuk inovasi penelitian selanjutnya dalam dunia Kesehatan khususnya bagi bidang keperawatan sebagai terapi tambahan dalam memberikan asuhan.

\section{Metode Penelitian}

Metode yang dilakukan dalam penelitian adalah penelitian kuantitatif melalui pendekatan cross sectional dengan metode penelitian Pra- Eksperimental Design. desain penelitian menggunakan One group pretest-posttest design, dimana peneliti hanya memberikan perlakuan saja tanpa menggunakan kelompok kontrol (Andi Ibrahim, Asrul Haq, 2018). Terdapat pretest sebelum diberi perlakuan, hasil perlakuan dapat diketahui dengan lebih akurat, karena dapat membandingkan dengan keadaan sebelum diberi perlakuan. Kelompok eksperimen akan dibagi menjadi 2 dan diberikan 
aromaterapi yang berbeda. Pada hari kedua diberikan posttes yang sama. Kemudian akan dibandingkan lewat hasil posttes tersebut.

Lokasi penelitian dilakukan di Ruang Parangtritis RSUD dr Saiful Anwar Malang. Ruang Parangtritis merupakan ruangan perawatan kelas 3 perempuan dewasa bagian dari RAWAT INAP (IRNA) I. Ruang Parangtritis sendiri memiliki ketersediaan tempat tidur sebanyak 37 bed. Dengan pasien rata-rata rujukan. Penelitian ini berlangsung selama bulan Juli-September 2021. Responden dalam penelitian ini adalah pasien post kemoterapi yang berusia 18-64 tahun dengan kriteria tidak memiliki gangguan penciuman dan Riwayat alergi terhadap aromaterapi serta pada saat penelitian bersedia tidak mengkonsumsi obat antiemetik selama 1x24 jam. Didapatkan sebanyak 38 responden yang dibagi menjadi 2 kelompok perlakuan sebanyak 19 pasien setiap aromaterapi yang disesuaikan menurut jenis kanker, siklus dan regimen kemoterapi yang sama. Instrument yang digunakan adalah kuosioner untuk pretest dan posttes, sedangkan untuk mual muntah pada penelitian ini diukur dengan mengggunakan kuesioner yang INVR (Rhodes index nausea, vomiting and retching) Kuesioner ini memiliki nilai validitas konstruk 0,87 dan reabilitas yang diuji dengan Alpha Chornbach 0,98. Index Nausea, Vomitting and Retching (INVR) memiliki 8 item pengkajian dan 5 skala likert. Rentang skor berkisar dari 0 sampai 32. Dimana: $0=$ tidak mual-muntah, 1-8 = mual-muntah ringan, 9-16 = mual-muntah sedang, 17-24 = mualmuntah berat, dan 25-32 = mual-muntah buruk (Ahmad, 2016).

Setelah melalui Proses editing dan coding data dari hasil pretest dan posttes dilakukan uji normalitas dan homogenitas data sebelum analisis uji pengaruh dan uji beda. Peneliti menggunakan Uji Shapiro-Wilk untuk menguji normalitas distribusi data berdasarkan hasil uji normalitas pada SPSS 26 for windows diketahui nilai signifikansi menggunakan shapiro wilk adalah sebesar $0,000<$ alpha 0,05 artinya data tidak berdistribusi normal. Dan Selanjutnya dilakukan uji homogenitas data menggunakan uji Levene's Test didapatkan nilai Based On Mean, yaitu dengan Sig (p value) > 0,05 yang berarti varians kedua kelompok sama atau yang disebut homogen. Maka asumsi kedua yaitu homogenitas telah terpenuhi

Kemudian dilakukan uji pengaruh menggunakan Wilcoxon Signed Rank ditemukan hasil yang sama baik aromaterapi peppermint dan lavender sebesar asymp.sig (2-tailed) $<0.000$ yang bernilai lebih kecil dari 0.005 Sehingga dapat disimpulkan bahwa terdapat pengaruh aromaterapi peppermint dan lavender terhadap mual muntah post kemoterapi di ruang parangtritis RSUD dr. Saiful Anwar Malang. Namun menurut uji beda menggunakan Mann Whitney $U$ didapatkan nilai Asymp. Signifikansi baik pretest maupun posttest yaitu lebih besar dari 0,05 sehingga dapat diartikan tidak terdapat perbedaan yang signifikan dari ke dua kategori aromaterapi yang terdiri dari peppermint dan lavender terhadap penurunan mual muntah post kemoterapi. Sehingga dapat disimpulkan bahwa tidak terdapat perbedaan efektivitas aromaterapi peppermint dan lavender terhadap penurunan mual muntah post kemoterapi di ruang Parangtritis RSUD dr Saiful Anwar Malang. 
Perbandingan Efektifitas Aroma Terapi Peppermint Dan Lavender Dalam Mengurangi Mual Dan Muntah Post Kemoterapi

\section{Hasil dan Pembahasan}

Dari total 38 Responden di Ruang Parangtritis RSUD dr Saiful Anwar Malang didapatkan data sebagai berikut:

Tabel 1

Gambaran Demografis Hasil Penelitian $(N=38)$

\begin{tabular}{lccc}
\hline Karakteristik Demografis & Aromaterapi Peppermint & Aromaterapi Lavender & \% \\
\hline 1. Jenis Kelamin & & & \\
\hline$\quad$ Perempuan & 19 & 19 & 100 \\
\hline 2. Usia & & & \\
\hline$\quad$ Remaja Akhir & 1 & 8 & 23,6 \\
\hline$\quad$ Dewasa Awal & 6 & 6 & 31,5 \\
\hline Dewasa Akhir & 7 & 2 & 23,6 \\
Lansia Awal & 3 & 2 & 13,1 \\
Lansia Akhir & 2 & 1 & 8,2 \\
\hline 3. Pendidikan & & & \\
\hline Dasar & 1 & 1 & 5,2 \\
\hline$\quad$ Menengah & 15 & 15 & 7,8 \\
\hline Tinggi & 3 & 3 & 16.8 \\
\hline
\end{tabular}

Melalui tabel 1 dapat diketahui bahwa responden dari penelitian berjumlah 38 Responden yang berjenis kelamin semua perempuan sebanyak $100 \%(n=38)$. Hampir setengahnya responden berada pada dewasa awal sebanyak 12 orang (31,5\%) dan Sebagian besar responden memiliki tingkat pendidikan menengah sebanyak 30 orang (78\%). Sedangkan untuk karakteristik Khusus Responden sebagai berikut:

Tabel 2

Gambaran Khusus Hasil Penelitian $(N=38)$

\begin{tabular}{cccc}
\hline & $\begin{array}{c}\text { Aromaterapi } \\
\text { Peppermint }\end{array}$ & $\begin{array}{c}\text { Aromaterapi } \\
\text { Lavender }\end{array}$ & $\%$ \\
\hline 1. Jenis Kanker & 4 & & \\
NHL & 1 & 4 & 21,1 \\
ALL & 1 & 1 & 5,2 \\
AML & 2 & 2 & 5,2 \\
Ca Broncho & 4 & 4 & 10,6 \\
Ca Colon & 3 & 3 & 21,1 \\
Ca Recti & 3 & 3 & 15,8 \\
Ca Cervix & 1 & 1 & 15,8 \\
Ca Mamae & 3 & & 5,2 \\
\hline 2. Stadium Kanker & 16 & 3 & 15,7 \\
3 & & 16 & 84,3 \\
4 & 1 & & \\
3. Siklus Kemoterapi & 4 & 1 & 5,2 \\
1 & 4 & 6 & 26,35 \\
2 & 0 & 6 & 26,35 \\
3 & 6 & 2 & 5,2 \\
4 & 4 & 2 & 21,1 \\
5 & & 2 & 15,8 \\
\hline 6 & & & \\
\hline
\end{tabular}


Hampir setengahnya kejadian kanker pada sampel adalah NHL (Non Hodgkin Limphoma) dan Ca Colon sebesar $21 \%$ atau 8 responden. Dan Sebagian Besar responden memiliki tingkat Stadium kanker 4 sebanyak 32 orang $(84,3 \%)$ sedangkan stadium 3 sebagian kecilnva sebanyak 6 orang $(15,7 \%)$. Sedangkan pada nilai siklus hampir setengahnya pada siklus 2 dan 3 yaitu 26\% (10 Responden). Dar hasil karakteristik responden di tabel diatas peneliti menemukan angka skor mual muntah post kemoterapi pada responden di ruang parangtritis RSUD dr Saiful Anwar Malang adalah sebagai berikut:

\section{Tabel 3}

Frekuensi Karakteristik Skor Mual Muntah Sebelum Pemberian Aromaterapi Pada Responden Post Kemoterapi Ruang Parangtritis RSUD dr. Saiful Anwar Malang

\begin{tabular}{ccccc}
\hline No & $\begin{array}{c}\text { Skor } \\
\text { Mual-Muntah }\end{array}$ & Peppermint & Lavender & Prosentase \\
\hline 1 & Mual-Muntah Ringan & 3 & 2 & 13.2 \\
2 & Mual-Muntah Sedang & 14 & 13 & 71 \\
3 & Mual Muntah Berat & 2 & 4 & 15,8 \\
\hline & Total & $\mathbf{1 9}$ & $\mathbf{1 9}$ & $\mathbf{1 0 0}$ \\
\hline
\end{tabular}

Berdasarkan tabel diatas diketahui bahwa Pada Umumnya mual muntah responden Post Kemoterapi terjadi pada skala mual muntah sedang sebanyak 27 Responden (71\%) Dan setelah diberikan perlakuan pemberian aromaterapi peppermint dan lavender mendapatkan hasil skor mual sebagai berikut:

\section{Tabel 4}

Frekuensi Karakteristik Skor Mual Muntah Setelah Pemberian Aromaterapi Pada Responden Post Kemoterapi Ruang Parangtritis RSUD dr. Saiful Anwar Malang

\begin{tabular}{ccccc}
\hline No & $\begin{array}{c}\text { Skor } \\
\text { Mual-Muntah }\end{array}$ & Peppermint & Lavender & Prosentase \\
\hline 1 & Tidak Mual-Muntah & 8 & 6 & 36,8 \\
2 & Mual-Muntah Ringan & 10 & 12 & 41,5 \\
3 & Mual Muntah Sedang & 1 & 1 & 21,7 \\
\hline & Total & $\mathbf{1 9}$ & $\mathbf{1 9}$ & $\mathbf{1 0 0}$ \\
\hline
\end{tabular}

Didapatkan penurunan hasil skor mual muntah setelah pemberian aromaterapi terjadi penurunan hampir sebagian menjadi mual muntah ringan sebesar 22 responden atau $41,5 \%$, Sedangkan tidak ada mual muntah sebanyak $36,8 \%$.

Kemudian dilakukan analisis pengaruh dari aromaterapi Peppermint terhadap mual muntah menggunakan Wilcoxon signed rank. Hasil yang didapatkan dalam pengolahan data tersebut disajikan pada tabel 5 . 


\section{Tabel 5}

Hasil Uji Pengaruh Pada Kelompok Aromaterapi Peppermint Menggunakan Wilcoxon Signed Rank

\begin{tabular}{llll}
\hline $\begin{array}{c}\text { SKOR } \\
\text { Mual-Muntah }\end{array}$ & Pretest & Posttest & $\boldsymbol{\rho}$-Value \\
\hline MEAN & 18,21 & 18,55 & 0,000 \\
\hline
\end{tabular}

Berdasarkan output test statistic menunjukkan hasil asymp.sig (2-tailed) $<0.000$ yang bernilai lebih kecil dari 0.005 Sehingga dapat disimpulkan bahwa terdapat pengaruh Aromaterapi Peppermint terhadap Mual Muntah Post kemoterapi di Ruang Parangtritis RSUD dr. Saiful Anwar Malang.Di dalam penelitian ini, peneliti juga melakukan analisis aromaterapi lavender terhadap menurunkan efek mual muntah post kemoterapi.

\section{Tabel 6}

Hasil Uji Pengaruh Pada Kelompok Aromaterapi Lavender Menggunakan Wilcoxon Signed Rank

\begin{tabular}{cccc}
\hline $\begin{array}{c}\text { SKOR } \\
\text { Mual-Muntah }\end{array}$ & Pretest & Posttest & $\boldsymbol{\rho}$-Value \\
\hline MEAN & 20,79 & 20,55 & 0,000 \\
\hline
\end{tabular}

Berdasarkan analisis diatas menunjukkan hasil asymp.sig (2-tailed) $<0.000$ yang bernilai lebih kecil dari 0.005 Sehingga dapat disimpulkan bahwa terdapat pengaruh Aromaterapi Lavender terhadap Mual Muntah Post kemoterapi di Ruang Parangtritis RSUD dr. Saiful Anwar Malang.Sebelum kita melanjutkan Uji U Mann-Whitney yang merupakan pengujian untuk mengetahui apakah ada perbedaan nyata antara mean data yang berasal dari 2 kelompok tidak berpasangan.

\section{Tabel 7}

Hasil Uji Perbedaan Skor Mual Muntah Antara Aromaterapi Peppermint Dan Lavender Menggunakan Mann Whitney

\begin{tabular}{cccc}
\hline $\begin{array}{c}\text { SKOR } \\
\text { Mual-Muntah }\end{array}$ & Peppermint & Lavender & $\boldsymbol{\rho}$-Value \\
\hline MEAN Pretest & 18,21 & 20,79 & 0,370 \\
MEAN Posttest & 18,55 & 20,45 & 0,546 \\
\hline
\end{tabular}

Tabel di atas dapat dilihat bahwa peringkat rata-rata (mean rank) tertinggi adalah pada aromaterapi lavender yaitu sebesar 20,45. Sedangkan peringkat rata-rata (mean rank) terendah yaitu pada aromaterapi peppermint sebesar 18,55. Dari sini kita dapat melihat untuk hasil post test lavender dalam menurunkan mual muntah post kemo lebih baik daripada peppermint.

Tabel 7

\begin{tabular}{|c|c|c|}
\hline \multicolumn{3}{|c|}{ Hasil Uji Mann Whitney } \\
\hline Pretest & Posttest & $\rho$-Value \\
\hline-.897 & -.604 & 0,546 \\
\hline
\end{tabular}


Kemudian dilanjutkan uji Mann Whitney dapat dilihat bahwa nilai Asymp. Signifikansi baik pretest maupun posttest didapatkan hasil yaitu lebih besar dari 0,05 sehingga dapat diartikan tidak terdapat perbedaan yang signifikan dari ke dua kategori aromaterapi yang terdiri dari peppermint dan lavender terhadap penurunan mual muntah post kemoterapi. Sehingga dapat disimpulkan bahwa tidak terdapat perbedaan efektivitas aromaterapi peppermint dan lavender terhadap penurunan mual muntah post kemoterapi di ruang Parangtritis RSUD dr Saiful Anwar Malang.

Berdasarkan hasil penelitian, ditemukan Aromaterapi Peppermint dan Lavender memiliki pengaruh terhadap penurunan mual muntah post kemoterapi. Peppermint sendiri memiliki kandungan mentol yang lumayan tinggi. Minyak atsiri ini mengandung mentol (7-48\%), hidroksitriptamin (5HT). Selanjutnya 5HT berinteraksi dengan reseptor 5HT3 pada aferen terminal vagus di dinding usus. Serabut aferen melanjutkan stimulasi ke dorsal brain steam yang berlokasi di komplek vagal dorsal. Komplek vagal dorsal merupakan tempat pusat reseptor untuk neurotransmitter yang memiliki peran potensial pada respon muntah, diantaranya neurokinin-1, 5HT3 dan reseptor dopamin 2, yang berikatan dengan substansi P, 5HT dan dopamin. Serabut eferen melanjutkan impuls tersebut ke efekter final dari refleks muntah yaitu pada sentral pattern generator (CPG) (Currlisa, 2020). Dan lavender memiliki sejarah panjang sebagai anticonvulsant, antidepressive, anxiolytic, sedative, dan penenang. Kandungan lavender oil terdiri dari: linalool, linalyl acetate, á- dan â- pinene dan 1,8- cineole. Dimana, linalyl acetat dan linalool adalah kandungan aktif utama pada lavender yang berperan sebagai efek anti cemas (relaksasi) dan meredakan nausea juga menghambat muntah (Ain et al., 2019). Dari beberapa efek kimiawi diatas dibantu dengan proses pemanasan partikel oleh burner menjadi molekul kecil yang dapat diserap oleh silia hidung. Proses penghiduan itu sendiri bermula dari molekul-molekul aromaterapi lavender yang dihirup secara inhalasi ditangkap oleh epitel olfaktorius ini yang kemudian diteruskan menuju sel nya. Pada sel olfaktorius terdapat silia yang berfungsi sebagai alas padat pada mukus yang bereaksi terhadap bau di udara. Sinyal ini akan diteruskan ke bulbus olfaktorius lalu ke akson-akson pendek dari sel olfaktorius dan berakhir di struktur globular yang lebih sering disebut glomeruli. Setiap ujung gromeruli memiliki dendrit untuk menerima sinaps dari sel olfaktorius yang akan menerima akson-akson ke traktus olfaktorius untuk menjalarkan sinyal-sinyal olfaktorius ke tingkat yang lebih tinggi ke sistem saraf pusat Dari sistem saraf pusat sensasi olfaktori diteruskan menuju sistem limbik lalu ke hipothalamus dan amygdala. Dari amygdala sensasi olfaktori memberikan efek perasaan tenang dan menurunkan nausea (Anisa et al., 2019) Meskipun sesuai penelitian aromaterapi peppermint dan lavender memiliki pengaruh menurunkan mual muntah kemoterapi, namun secara efektifitas dalam menurunkan skor mual muntah tidak ada perbedaan, Berbeda dengan penelitian yang dilakukan (Safaah Siti, 2019) tentang perbandingan aromaterapi peppermint dan lavender terhadap skala nyeri Post SC ditemukan Terdapat perbedaan yang signifikan penurunan skala nyeri pada kelompok lavender dan kelompok peppermint. Gambaran skala nyeri sebelum intervensi pada kelompok lavender mayoritas yaitu pada skala nyeri 7 (berat). Sedangkan pada 
kelompok peppermint, mayoritas yaitu pada skala nyeri 6 (sedang). Gambaran skala nyeri setelah intervensi pada kelompok lavender mayoritas yaitu pada skala Nyeri 5 (sedang). Sedangkan pada aromaterapi peppermint mayoritas yaitu pada skala Nyeri 4 (sedang). Serta penelitian (Zuraida, 2018) tentang Perbedaan efektivitas pemberian essensial oil peppermint dan aroma terapi lavender terhadap intensitas mual dan muntah pada ibu hamil trimester I dapat disimpulkan bahwa Terdapat perbedaan efektifitas pemberian essensial oil peppermint dan aroma terapi lavender terhadap penurunan intensitas mual dan muntah pada ibu hamil, dimana pemberian essensial oil peppermint lebih efektif terhadap penurunan intensitas mual dan muntah pada ibu hamil trimester I.

Menurut opini peneliti pada dasarnya mekanisme penurunan intensitas mual muntah pada pasien post kemoterapi baik yang diberikan aroma essensial oil peppermint maupun yang diberikan aroma terapi lavender hampir sama, dimana kedua intervensi ini sama-sama bersifat anti depresan karena kandungan atsiri dan aroma terapi yang dimilikinya. Pemberian aroma aroma essensial oil peppermint dan aroma terapi lavender sama-sama memberikan efek kenyamanan dan peningkatan relaksasi tubuh sehingga memperbaiki kondisi psikologis yang menjadi pemicu mual muntah pada pasien post kemoterapi. Apabila tingkat relaksasi tubuh meningkat maka akan menurunkan tingkat stress dan dengan menurunnya tingkat stress juga akan menurunkan intensitas mual dan muntah pada pasien post kemoterapi. Aromaterapi peppermint dan lavender dapat menurunkan rata-rata 1-2 skala mual muntah. Dalam penelitian ini peneliti mendapatkan efek aromaterapi masih jangka pendek dalam menurunkan mual sehingga diperlukan pemakaian aromaterapi lebih dari 3 kali sehari apabila menginginkan hasil maksimal untuk skor mual berat dan kebanyakan jika mual muntah buruk responden menginginkan gabungan dengan terapi farmakologis agar mendapatkan efek yang lebih cepat.

\section{Kesimpulan}

Hasil dari penelitian ini menunjukkan skor mual responden diketahui bahwa sebagian besar responden memiliki mual muntah sedang lebih banyak dibandingkan mual muntah ringan dan mual mual muntah berat, dimana mual muntah sedang sebanyak 27 responden atau $71 \%$ sedangkan sisanya mual muntah ringan dan berat masing-masing sebanyak 5 dan 6 Responden. Baik aromaterapi peppermint dan lavender memiliki pengaruh terhadap penurunan mual muntah post kemoterapi di ruang Parangtritis RSUD dr. Saiful Anwar Malang. Meskipun begitu tidak terdapat perbedaan efektivitas yang signifikan dari ke dua kategori aromaterapi yang terdiri dari peppermint dan lavender terhadap penurunan mual muntah post kemoterapi.

Peneliti memberikan saran untuk penelitian selanjutnya sebaiknya memperluas penelitian dengan menambahkan variabel dalam penelitian, atau menggunakan metode pemberian aromaterapi yang lain, sehingga diperoleh informasi yang lebih lengkap tentang perbandingan pengaruh pemberian aromaterapi sehingga menambah khasanah penelitian khususnya dalam keperawatan. 


\section{BIBLIOGRAFI}

Ahmad, M. (2016). Tool Development to Assess Nause ts Receiving Chemotherapy. International Journal of Cancer and Oncology, 3(1), 1-5. Google Scholar

Ain, A., Agung, D. G., \& Yunitasari, E. (2019). Aromaterapi Lavender dalam Upaya menurunkan Nausea dan Vomiting Pasien Kanker Payudara yang Menjalani Kemoterapi di RSUD Dr. Soetomo Surabaya. Jurnal Ners Dan Kebidanan (Journal of Ners and Midwifery), 6(3), 401-407. Google Scholar

Andi Ibrahim, Asrul Haq, M. (2018). Metodologi Penelitian (M. S. Dr. H. Ilyas Ismail, M.Pd. (ed.)). Google Scholar

Anisa, A., Agung, D. G., Yunitasari, E., \& Kunci, K. (2019). Aromaterapi Lavender Dalam Upaya Menurunkan. 401-407. Google Scholar

Arifah, N. (2018). Aromatherapy for The Management and Control Effect of Chemoterapy: A Systematic Review. 521-529. Google Scholar

Currlisa. (2020). Peppermint Oil Evaluating Efficacy On Nausea In Patients Receiving Chemotherapy In The Ambulatory Setting. Peppermint Oil Evaluating Efficacy On Nausea In Patients Receiving Chemotherapy In The Ambulatory Setting, 24(2).

Gupta, K., Walton, R., \& Kataria, S. P. (2021). Chemotherapy-Induced Nausea and Vomiting: Pathogenesis, Recommendations, and New Trends. Cancer Treatment and Research Communications, 26(December 2020), 100278. Google Scholar

Hamdani, D., \& Anggorowati, A. (2019). Intervensi Untuk Mengatasi Mual Antisipatori Pada Pasien Kanker Yang Menjalani Kemoterapi: A Litelatur Review. Jurnal Smart Keperawatan, 6(1), 65. Google Scholar

Iihara, H., Fujii, H., Yoshimi, C., Yamada, M., Suzuki, A., Matsuhashi, N., Takahashi, T., Yoshida, K., \& Itoh, Y. (2016). Control of chemotherapy-induced nausea in patients receiving outpatient cancer chemotherapy. International Journal of Clinical Oncology, 21(2), 409-418. Google Scholar

Ministry of Health RI. (2019). Infodatin-cancer burden 2019. Jakarta: Ministry of Health RI., 3-6. Google Scholar

Nindya, \& Surarso, B. (2016). Terapi mual muntah pasca kemoterapi. Jurnal THT - KL, 9(2), 74-83. Google Scholar

Petrarizky, A. J., \& Nugroho, R. S. (2020). Laporan Tahunan Pelayanan Radioterapi di RSUD Dr. Saiful Anwar Malang Tahun 2018. Radioterapi \& Onkologi Indonesia, 10(2), 43-48. Google Scholar

Rapoport, B. L. (2017). Delayed chemotherapy-induced nausea and vomiting: Pathogenesis, incidence, and current management. Frontiers in Pharmacology, 
Perbandingan Efektifitas Aroma Terapi Peppermint Dan Lavender Dalam Mengurangi Mual Dan Muntah Post Kemoterapi

8(JAN), 1-10. Google Scholar

Rukayah, S. (2015). Pengaruh Terapi Akupresur Terhadap Mual Muntah Lambat Akibat Kemoterapi Pada Anak Usia Sekolah Yang Menderita Kanker Di Rs Kanker Dharmais Jakarta. Pediatric Nursing, 118. Google Scholar

Safaah Siti, Purnawan Iwan, S. Y. (2019). Perbedaan Efektivitas Aromaterapi Lavender dan Aromaterapi Peppermint terhadap Nyeri pada Pasien Post -Sectio Caesarea di RSUD Ajibarang. Journal of Bionursing, 1(1), 47-65. Google Scholar

Sari, R. I., Hartoyo, M., \& Wulandari. (2015). Pengaruh aromaterapi peppermint terhadap penurunan mual di SMC RS Telogorejo. Jurnal Ilmu Keperawatan Dan Kebidanan (JIKK), 1-9. Google Scholar

Zuraida, \& Desia, S. E. (2018). Perbedaan Efektivitas Pemberian Essensial Oil Peppermint dan Aroma Terapi Lavender terhadap Intensitas Mual dan Muntah pada Ibu Hamil Trimester I di Puskesmas Baso Kabupaten Agam Tahun 2017. Jur, 12(4), 142-151. Google Scholar

\section{Copyright holder:}

Lailatus Siyamu Nurrohmi, Sih Ageng Lumadi, Risna Yekti Mumpuni (2021)

First publication right:

Syntax Literate: Jurnal Ilmiah Indonesia

This article is licensed under: 